\title{
BILANGAN TERHUBUNG TITIK PELANGI UNTUK GRAF LINGKARAN BINTANG $\left(S_{m} C_{n}\right)$
}

\author{
Ariestha Widyastuty Bustan \\ Program Studi Matematika, Fakultas Matematika dan Ilmu Pengetahuan Alam \\ Universitas Pasifik Morotai, Jl Siswa Darame, Kec. Morotai Selatan, \\ Kab. Pulau morotai, Maluku Utara, Indonesia \\ e-mail: ariesthawidyastutybustan@gmail.com
}

\begin{abstract}
Abstrak
Pewarnaan pada graf $G=(V(G), E(G))$ dikatakan terhubung titik pelangi, jika untuk setiap dua titik yang berbeda $u$ dan $v$ di $V(G)$, terdapat lintasan $u-v$ dengan semua titik internalnya memiliki warna yang berbeda. Bilangan terhubung titik pelangi dari $G$, dinotasikan dengan $\operatorname{rvc}(G)$, adalah minimum banyak warna yang dibutuhkan sehingga $G$ terhubung titik pelangi. Misalkan $m$ dan $n$ adalah dua bilangan bulat positif dengan $m \geq 3$ dan $n \geq 3, S_{m}$ adalah graf bintang dengan $m+1$ titik, dan $C_{n}$ adalah graf lingkaran dengan $n$ titik. Graf lingkaran bintang $\left(S_{m} C_{m}\right)$ adalah graf yang diperoleh dengan menempelkan satu salinan graf $C_{n}$ ke masing-masing titik pendant graf $S_{m}$. Pada paper ini ditentukan bilangan terhubung titik pelangi untuk graf lingkaran bintang.
\end{abstract}

Kata Kunci: bilangan terhubung titik pelangi, bintang, lingkaran, pewarnaan pelangi.

\section{THE RAINBOW VERTEX CONNECTION NUMBER OF STAR CYCLE GRAPHS $\left(S_{m} C_{n}\right)$}

\begin{abstract}
A vertex-colored graph $G=(V(G), E(G))$ is said to be rainbow vertex-connected, if for every two vertices $u$ and $v$ in $V(G)$, there exist a $u-v$ path with all internal vertices have distinct colors. The rainbow vertex-connection number of $G$, denoted by $\operatorname{rvc}(G)$, is the smallest number of colors needed to make $G$ rainbow vertex-connected. Let $m$ and $n$ be two integers at least $3, S_{m}$ be a star with $m+1$ vertices, and $C_{n}$ be a cycle with $n$ vertices. A star cycle $\left(S_{m} C_{n}\right)$ is a graph obtained by embedding a copy of $C_{n}$ to each pendant of $S_{m}$. In this paper, we determine the rainbow vertex connection number of star cycle graphs.
\end{abstract}

Keywords: cycle, rainbow vertex-coloring, rainbow vertex connection-number, star.

\section{Pendahuluan}

Misalkan $G$ adalah graf sederhana, berhingga dan terhubung tak trivial, maka didefinisikan suatu pewarnaan titik dari $G$ yaitu $\alpha: V(G) \rightarrow\{1,2, \ldots, n\}$ untuk suatu bilangan bulat $n$ sedemikian sehingga untuk setiap dua titik yang bertetangga memiliki warna yang berbeda. Suatu lintasan $P$ pada $G$ merupakan lintasan titik pelangi jika titik-titik dalam lintasan $u-v$ untuk setiap $u, v \in V(G)$ memiliki warna yang berbeda. Pewarnaan titik pada $G$ dikatakan terhubung titik pelangi, jika setiap dua titik dihubungkan oleh paling sedikit satu lintasan titik pelangi. Bilangan terhubung titik pelangi dari graf terhubung $G$, dinotasikan dengan $\operatorname{rvc}(G)$, adalah warna minimum yang dibutuhkan untuk membuat $G$ terhubung titik pelangi.

Krivelevich dan Yuster memberikan batasan untuk bilangan terhubung titik pelangi, yaitu

Teorema 1.1 Misalkan $n \geq 3$ dan $G$ graf terhubung dengan $n$ titik, maka $(G)-1 \leq \operatorname{rvc}(G) \leq n-2$.

Teorema 1.2 Misalkan $G$ graf terhubung dengan $c$ titik pemotong, maka $r v c(G) \geq c$. 


\section{Hasil dan Pembahasan}

Definisi 2.1. Misalkan $m$ dan $n$ adalah adalah dua bilangan positif dengan $m \geq 3$ dan $n \geq 3, S_{m}$ adalah graf bintang dengan $m+1$ titik, $C_{n}$ adalah graf lingkaran dengan $n$ titik. Graf lingkaran bintang yang dinotasikan dengan dengan $S_{m} C_{n}$ adalah graf yang diperoleh dengan menempelkan satu salinan graf $C_{n}$ ke masingmasing titik pendant graf $S_{m}$.

Graf $S_{m} C_{n}$ memiliki himpunan titik dan himpunan sisi yang dituliskan secara berturut-turut sebagai berikut:

$$
\begin{aligned}
& V\left(S_{m} C_{n}\right)=\left\{v_{i, j} \mid i, j \in[1, m]\right\} \cup\left\{v_{m+1}\right\}, \text { dan } \\
& E\left(S_{m} C_{n}\right)=\left\{v_{m+1} v_{i, 1} \mid i \in[1, m]\right\} \cup\left\{v_{i, j} v_{i, j+1} \mid i \in[1, m], j \in[1, m-1]\right\} \\
& \cup\left\{v_{i, m} v_{i, 1} \mid i \in[1, m]\right\} \cup\left\{v_{i, j} v_{i, j+\frac{m}{2}} \mid i \in[1, m], j \in\left[1, \frac{m}{2}\right]\right\}
\end{aligned}
$$

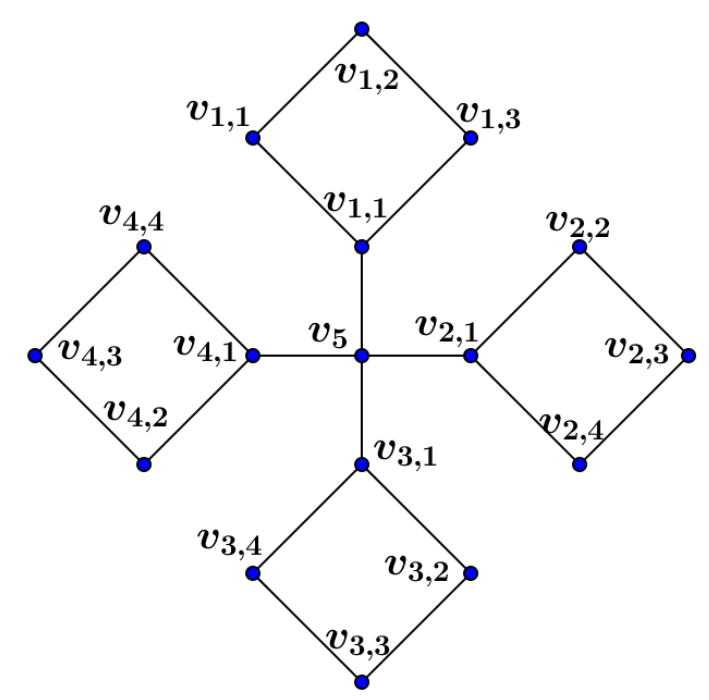

Gambar 1. Graf $S_{4} C_{4}$

Teorema 2.2. Misalkan $m$ dan $n$ adalah adalah dua bilangan positif dengan $\geq 3$ dan $n \in[3,5] . S_{m} C_{n}$ adalah graf lingkaran bintang, maka

$$
\operatorname{rvc}\left(S_{m} C_{n}\right)=\left\{\begin{array}{lr}
\text { diam }-1 & \text { untuk } S_{3} C_{4} \\
c & \text { untuk } m \geq 3 n=3 \\
& \text { untuk } m \geq 4 \text { dan } n=4 \\
\text { diam } & \text { untuk } S_{3} C_{5} \\
\text { diam }+1 & \text { untuk } S_{4} C_{5}
\end{array}\right.
$$

\section{Bukti.}

Kasus 1. $r v c\left(S_{3} C_{4}\right)=5$

Berdasarkan teorema 1.1 diperoleh $\operatorname{rvc}\left(S_{3} C_{4}\right) \geq \operatorname{diam}\left(S_{3} C_{4}\right)-1=6-1=5$. Sehingga diperoleh suatu pewarnaan 5-titik pelangi paga graf $S_{3} C_{4}$ seperti yang ditunjukkan pada Gambar 2 . 


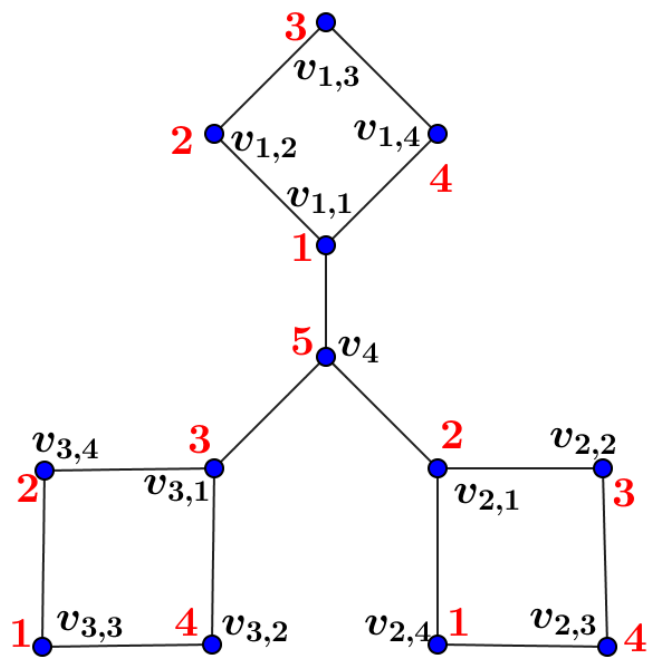

Gambar 2. Graf $S_{3} C_{4}$

Kasus 2. $r v c\left(S_{m} C_{n}\right)=c$

Berdasarkan teorema 1.2 diperoleh $\operatorname{rvc}\left(S_{m} C_{n}\right) \geq c=m+1$. Selanjutnya akan didefinisikan suatu pewarnaan $\alpha: V\left(S_{m} C_{n}\right) \rightarrow[1, m+1]$ sebagai berikut:

$\alpha\left(v_{m+1}\right)=m+1$

$\alpha\left(v_{i, j}\right)= \begin{cases}i+j-1, & \text { jika } i+j \leq m+1, \text { dan } i, j \in[1, m] \\ (i+j) \bmod (m+1), & \text { lainnya. }\end{cases}$

Kasus 3. $r v c\left(S_{3} C_{5}\right)=$ diam

Berdasarkan teorema 1.1, diperoleh $\operatorname{rvc}\left(S_{3} C_{5}\right) \geq \operatorname{diam}-1=6-1=5$. Andaikan terdapat suatu pewarnaan titik pelangi pada $\left(S_{3} C_{5}\right)$ dengan 5 warna. Tanpa mengurangi keumuman warnai titik pemotong dengan warna berbeda dengan aturan sebagai berikut:

$\alpha^{\prime}\left(v_{m+1}\right)=m+1$

$\alpha^{\prime}\left(v_{i, m+1}\right)=i, i \in[1, m]$

Perhatikan titik $v_{1,4}$ dan titik $v_{3,4}$, satu-satunya lintasan yang menghubungkan kedua titik tersebut dengan panjang sama dengan diameter adalah lintasan $v_{1,4}, v_{1,5}, v_{1,1}, v_{4}, v_{3,1}, v_{3,5}, v_{3,4}$. Hal ini mengakibatkan $v_{1,5}$ atau $v_{3,5}$ harus diwarnai dengan salah satu warna yang ada pada titik pemotong yaitu warna 2 . Misalkan $v_{1,5}$ diwarnai dengan warna 2 , maka tidak terdapat lintasan titik pelangi yang menghubungkan titik $v_{1,4}$ dengan $v_{2,4}$. Misalkan $v_{3,5}$ diwarnai dengan warna 2 maka tidak terdapat lintasan titik pelangi yang menghubungkan titik $v_{3,4}$ dengan $v_{2,4}$. karena pada graf $\left(S_{3} C_{5}\right)$ tidak berlaku pewarnaan 5-titik pelangi, maka diperoleh

$$
\operatorname{rvc}\left(S_{3} C_{5}\right) \geq 6=\text { diam }
$$

Selanjutnya akan dibuktikan $\operatorname{rvc}\left(S_{3} C_{5}\right) \leq 6$ dengan mendefinisikan pewarnaan 6-titik pelangi untuk graf $S_{3} C_{5}$ seperti pada Gambar 3. 


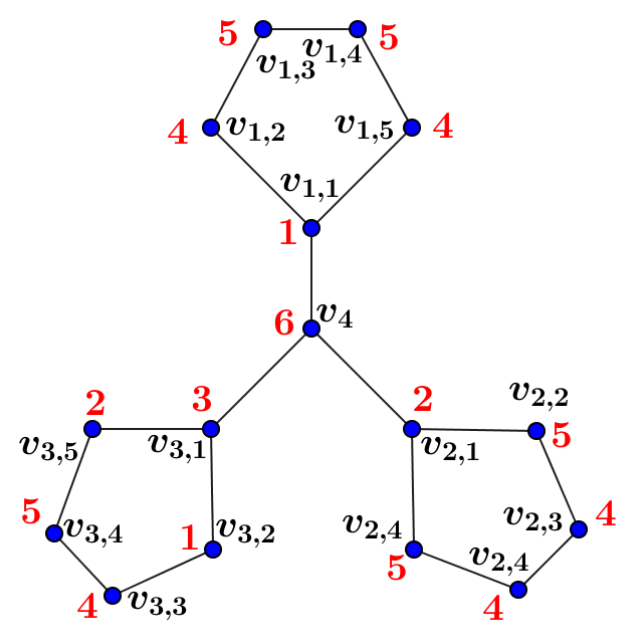

Gambar 3. Graf $S_{3} C_{5}$

Kasus 4. $r v c\left(S_{4} C_{5}\right)=$ diam +1

Andaikan terdapat suatu pewarnaan titik pelangi pada $\left(S_{4} C_{5}\right)$ dengan diam $=6$ warna. Tanpa mengurangi keumuman warnai titik pemotong dengan warna berbeda dengan aturan sebagai berikut:

$$
\begin{aligned}
& \alpha^{\prime}\left(v_{m+1}\right)=m+1 \\
& \alpha^{\prime}\left(v_{i, m+1}\right)=i, i \in[1, m]
\end{aligned}
$$

Perhatikan titik-titik $v_{i, 2}$ dan $v_{i, 5}$, pasti ada yang diwarnai dengan warna pada titik pemotong, misal $v_{l, 2}$ yang diwarnai dengan warna yang ada pada titik pemotong dan dimisalkan dengan warna $k$, maka titik $v_{k, 2}$ dan titik $v_{k, 5}$ harus diwarnai dengan warna yang sama. Jika warna yang sama tersebut adalah warna pada titik pemotong, maka tidak terdapat pewarnaan titik pelangi untuk lintasan yang melalui titik pemotong tersebut. Sebaliknya jika warna yang sama adalah warna yang tidak digunakan pada titik pemotong, maka perhatikan titik $v_{l, 5}$, titik tersebut pasti diwarnai dengan warna yang ada pada titik pemotong, misal diwarnai dengan warna $m \neq \alpha^{\prime}\left(v_{l, 2}\right)$. Selanjutnya perhatikan titik-titik $v_{m, 2}$ dan titik $v_{m, 5}$ harus diwarnai dengan warna yang sama, hal ini mengakibatkan tidak terdapat lintasan titik pelangi yang melewati titik potong yang diwarnai dengan warna $m$. Karena pada graf $\left(S_{4} C_{5}\right)$ tidak berlaku pewarnaan 6-titik pelangi, maka diperoleh

$$
\operatorname{rvc}\left(S_{4} C_{5}\right) \geq 7=\operatorname{diam}+1
$$

Selanjutnya akan dibuktikan $\operatorname{rvc}\left(S_{4} C_{5}\right) \leq 7$ dengan mendefinisikan pewarnaan 7 -titik pelangi untuk graf $S_{4} C_{5}$ seperti pada Gambar 4.

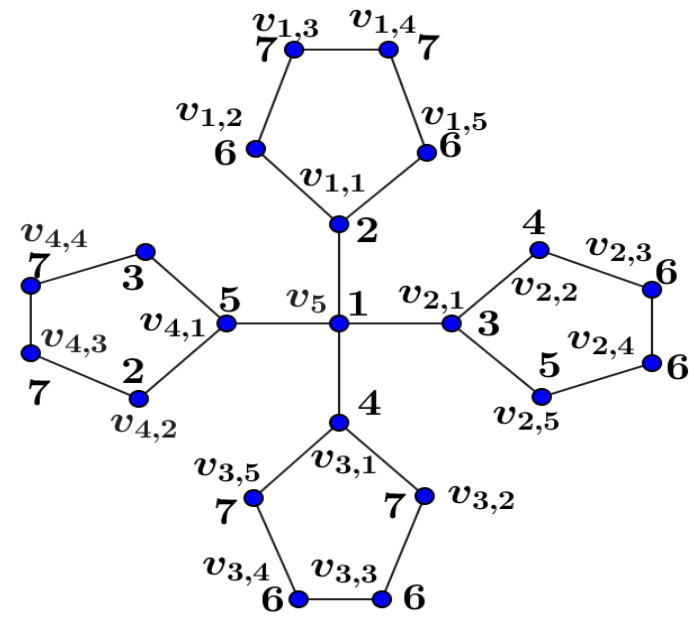

Gambar 4. Graf $S_{4} C_{5}$ 


\section{Kesimpulan}

Berdasarkan hasil dan pembahasan, diperoleh dapat disimpulkan bahwa bilangan terhubung titik pelangi untuk graf lingkaran bintang $\left(S_{m} C_{n}\right)$ adalah sebagai berikut:

Misalkan $m$ dan $n$ adalah adalah dua bilangan positif dengan $\geq 3$ dan $n \in[3,5] . \quad S_{m} C_{n}$ adalah graf lingkaran bintang, maka

$$
\operatorname{rvc}\left(S_{m} C_{n}\right)=\left\{\begin{array}{lr}
\text { diam }-1 & \text { untuk } S_{3} C_{4} \\
c & \text { untuk } m \geq 3 n=3 \\
\text { untuk } m \geq 4 \text { dan } n=4 \\
\text { diam } & \text { untuk } S_{3} C_{5} \\
\text { diam }+1 & \text { untuk } S_{4} C_{5}
\end{array}\right.
$$

\section{Daftar Pustaka}

[1] Krivelevich, M. Yuster, R., The Rainbow Connection of a Graph is (at most) reciprocal to its minimum degree. Graph Theory., 2010..

[2] X. d. S. Li, Tight Upper Bound of The Rainbow vertex-connection for 2-connected graphs. Discrete Applied Mathematics, 2014, pp. 62-69. 